\title{
Pengaruh Pemberian Senyawa Taurin dan Ekstrak Daun Dewa Gynura segetum (Lour) Merr terhadap Eritrosit dan Leukosit Mencit (Mus musculus) yang Diinduksi Benzo[a]Piren
}

\author{
Henny Marlinda ${ }^{1,2)}$, Endang LinirinWidiastuti2*, \\ G. Nugroho Susanto' ${ }^{2)}$, dan Sutyarso ${ }^{2)}$ \\ ${ }^{1}$ Fakultas Matematika dan Ilmu Pengetahuan Alam, Program Studi Magister Biologi, \\ Universitas Lampung, Bandar Lampung 35145 \\ ${ }^{2}$ Fakultas Matematika dan Ilmu Pengetahuan Alam, Jurusan Biologi, \\ Universitas Lampung, Bandar Lampung 35145
}

Diterima 28-07-2015 Disetujui 03-03-2016

\begin{abstract}
Blood cancer (leukemia) is a cancer that occurs due to malignancy of blood cells. Treatment of leukemia generally causes damage to normal cells. Therefore, it needs a drug that has the effect of repairing cell damage and the ability to boost immunity of normal such as taurine and Gynura leaves which are expected to have anticancer and antioxidant properties. The purpose of this study was to investigate the effect of taurine and dewa leaf extract on blood tissues induced by benzo $[\alpha]$ pyrene in vivo, by looking at changes in body weight, the number of red blood cells (erythrocytes), the total number and differentiation of white blood cells (leukocytes) in mice (Mus musculus). Data were analyzed by One Way ANOVA test followed by LSD at $5 \%$ significance level. The treatment groups were the group I was given $0.2 \mathrm{~mL}$ of corn oil (negative control), group II (given benzo [ $\alpha$ ] pyrene as a positive control, Group III (given taurine $7.8 \mathrm{mg} / \mathrm{BW} /$ day starting from day 1 to 15 before the induction of benzo [ $\alpha$ ] pyrene until the end of the study), Group IV was given benzo [ $\alpha$ ] pyrene, then were given taurine $7.8 \mathrm{mg} / \mathrm{BW} /$ day were given 2 times a day, as well as the $\mathrm{V}$ group was given benzo $[\alpha]$ pyrene, then given a dose of Gynura leaf extract $277.8 \mathrm{mg} / \mathrm{BW} /$ day. The results showed taurine and Gynura leaf extract were able to obstruct leukemia by increasing body weight, erythrocyte, leukocyte, and the number of leukocyte differentiation which becomes normal again. In conclusion taurine has better ability for therapoitic than Gynura leaf extact against blood cells induced by benzo[ $\alpha]$ piren
\end{abstract}

Keywords: benzo [ $\alpha]$ pyrene, erythrocyte, Gynura segetum (Lour) Merr, leukocyte, taurine

\begin{abstract}
ABSTRAK
Kanker darah (leukemia) merupakan salah satu penyakit kanker yang terjadi karena keganasan sel-sel darah. Pengobatan leukemia umumnya menyebabkan kerusakan pada sel-sel normal. Oleh karena itu dibutuhkan obat yang mempunyai efek memperbaiki kerusakan sel dan meningkatkan imunitas sel-sel normal seperti taurin dan daun dewa yang diduga mempunyai sifat antikanker dan antioksidan. Tujuan dari penelitian ini adalah untuk mengetahui pengaruh taurin dan ekstrak daun dewa terhadap jaringan darah yang diinduksi benzo[ $\alpha]$ piren secara in vivo, dengan melihat perubahan berat badan, jumlah sel darah merah (eritrosit), jumlah total dan jenis sel darah putih (leukosit) pada mencit (Mus musculus). Data dianalisis dengan One Way ANOVA dilanjutkan uji BNT taraf nyata 5\%. Kelompok perlakuan yaitu kelompok I diberi 0,2 mL minyak
\end{abstract}

*Telp: +6285378832689

Email: hen.marlinda@gmail.com 
jagung (sebagai kontrol negatif), II (diberi benzo[ $\alpha$ ]piren sebagai kontrol positif), kelompok III (diberi taurin 7,8 mg/BB/hari dimulai sejak hari ke 1 sampai ke 15 sebelum induksi benzo[ $\alpha]$ piren sampai akhir penelitian), Kelompok IV diberi benzo[ $\alpha]$ piren, selanjutnya diberi taurin 7,8 mg/BB/hari yang diberi 2 kali sehari, serta kelompok $\mathrm{V}$ diberi benzo[ $\alpha]$ piren, kemudian diberi ekstrak daun dewa dosis $277,8 \mathrm{mg} / \mathrm{BB} /$ hari. Hasil penelitian menunjukkan taurin dan daun dewa mampu menghambat pembentukan leukemia dengan mengembalikan kondisi berat badan, eritrosit, leukosit, dan jenis leukosit menjadi normal kembali. Kesimpulan penelitian ini taurin mempunyai kemampuan terapoetik terhadap sel-sel darah yang diinduksi benzo $[\alpha]$ piren serta taurin mempunyai kemampuan lebih baik dari ekstrak daun dewa.

Kata kunci: benzo[ $\alpha]$ piren, eritrosit, Gynura segetum (Lour) Merr, leukosit, taurin

\section{PENDAHULUAN}

Kanker merupakan penyakit kelainan pada sel-sel normal dengan ciri berupa terjadinya pertumbuhan sel-sel jaringan tubuh yang tidak normal dan terkendali (Sundaryono 2012). Kanker dapat disebabkan oleh faktor endogen maupun eksogen. Faktor endogen dapat berupa faktor genetik, penyakit, dan hormon, sedangkan faktor eksogen dapat berasal dari makanan, virus, senyawasenyawa karsinogenik seperti polusi udara, zat warna, logam-logam karsinogen, dan banyak penyebab lainnya seperti siklofosfamida (Hanahan \& Weinberg 2000).

Pertumbuhan dan perkembangan yang tidak normal pada sel-sel darah dapat berubah menjadi sel- sel ganas. Keganasan dari sel-sel darah yang tidak terkendali dan terdeteksi, sehingga ada perubahan jumlah eritrosit dan leukosit yang merupakan salah satu jenis penyakit serius adalah leukemia (Sundaryono 2012). Leukemia memiliki sifat ganas pada jaringan darah yang akhirnya dapat menyebabkan kematian. Kekurangan jumlah sel-sel darah merah merupakan kelainan hematologi yang biasa dan sering ditemukan pada pasien kanker. Banyak pasien telah didiagnosis menderita anemia akibat berbagai penyakit kronik, seperti kanker (Syafei 2009).

Taurin (asam 2-aminoethanesulfonic) adalah $\beta-A A$ dan asam amino yang paling banyak pada mamalia, yang didistribusikan secara luas di dalam sistem saraf pusat (SSP) dan menempati tempat kedua setelah glutamat dalam kaitannya dengan konsentrasi. Peran taurin dalam sel tampaknya ditentukan oleh jenis sel. Taurin sebagai antikanker dimungkinkan melalui antioksidasi, immunomodulasi, peningkatan perbaikan pada DNA dan penghambatan proliferasi sel (Xia Zhang et al. 2008).

Penelitian lain tentang peran protektif dari taurin terhadap stres oksidatif pada polimer dinding sel eritrosit (murine) telah dibuktikan (Hynek et al. 2012). Hal ini yang bisa membuktikan bahwa taurin menjadi bermanfaat di bidang kesehatan (Stapleton et al. 1998). Penelitian ini membuktikan kandungan taurin pada tubuh manusia bisa bersifat terapoitik dan protektif terhadap beberapa penyakit.

Selain itu, taurin dilaporkan dapat menginduksi produksi reduced glutathione (GSH) pada organ yang berbeda (Anand et al. 2011). Induksi ini terhubung dengan efek perlindungan dari taurin pada glutathione dan tergantung enzim glutathione (Pushpakiran et al. 2004). Taurin telah terbukti menjadi pengobatan yang efektif untuk jantung kongestif dan untuk melindungi terhadap efek buruk dari spesies oksigen reaktif (ROS) (Stapleton et al. 1998).

Daun dewa mengandung alkaloid, saponin, pFlavonoid, minyak atsiri dan tannin (Rivai 2012). Kandungan flavonoid pada daun dewa juga merupakan anti oksidan sehingga mampu menangkal radikal bebas. Dari hasil penelitian sebelumnya diketahui bahwa senyawa flavonoid tanaman ini mampu meningkatkan jumlah eritrosit dan menurunkan jumlah leukosit pada tikus yang diinduksi BaP (Sundaryono 2012).

Benzo $[\alpha]$ pyrene adalah salah satu Hidrokarbon aromatic policiclic (PAH) yang diurutkan sebagai zat karsinogenik Kelas-I oleh Badan Internasional untuk Penelitian Kanker (IARC 2010). Secara in vivo, benzo $[\alpha]$ pyrene telah terbukti menyebabkan tumor pada setiap hewan percobaan, baik melalui jalur makanan, pernafasan, maupun kontak pada permukaan kulit. Inisiasi proses karsinogenik dari benzo[ $\alpha]$ pyrene bahkan dapat terjadi pada bagian jaringan yang jauh dari titik asal paparannya. Penelitian terbaru oleh Gangar et al. (2010), induksi zat karsinogen benzo[ $\alpha]$ pyrene pada tikus memperlihatkan efek berat badan dan hemotologi yang signifikan pada jumlah eritrosit, jumlah leukosit, dan diferensiasi leukosit secara 
menyeluruh, dan merupakan indikator penting pada proses karsinogenesis atau tumorigenesis pada tikus.

Pada penelitian ini dilakukan pengujian efek antikanker dari taurin secara in vivo pada mencit yang diinduksi benzo $[\alpha]$ piren $(\mathrm{BaP})$. Belum ada penelitian tentang efek antikanker dari taurin terhadap abnormalitas jaringan yang diinduksi benzo $[\alpha]$ piren, sehingga perlu dilakukan uji efek antikanker dari taurin terhadap mencit jantan (Mus musculus).

Penelitian ini bertujuan untuk mengetahui pengaruh taurin dan daun dewa terhadap kerusakan sel-sel darah mencit (Mus musculus) yang diinduksi BaP.

\section{BAHAN DAN METODE}

Penelitian dilakukanpada bulan Desember 2014Februari 2015. Pemeliharaan mencit dan pemberian taurin dilakukan di Laboratorium Biologi Molekuler Fakultas Matematika dan Ilmu Pengetahuan Alam Universitas Lampung. Pembedahan dan proses pengamatan hematology dilakukan di Balai Penyidikan dan Pengujian Veteriner (BPPV) Regional III Bandar Lampung. Materi utama yang digunakan dalam penelitian ini adalah senyawa uji taurin dan karsinogen BaP.

Penelitian dilakukan dengan Rancangan Acak Lengkap (RAL) dengan lima kali pengulangan. Dosis taurin yang digunakan 7,8 mg/BB/hari dan 15,6 mg/BB/hari. Sedangkan induksi BaP yaitu $0,3 \mathrm{mg} / \mathrm{BB}$ mencit/hari dalam $0,2 \mathrm{~mL}$ minyak jagung selama 10 hari (Sugitha \& Djalil 1989). Kelompok perlakuan yaitu kelompok I diberi 0,2 mL minyak jagung (sebagai kontrol negatif), II (diberi benzo[ $[\boldsymbol{\alpha}]$ piren sebagai kontrol positif), kelompok III (diberi taurin 7,8 mg/BB/hari dimulai sejak hari ke 1 sampai ke 15 sebelum induksi benzo $[\alpha]$ piren sampai akhir penelitian), Kelompok IV diberi benzo[ $\alpha]$ piren, selanjutnya diberi taurin $7,8 \mathrm{mg} /$ $\mathrm{BB} /$ hari yang diberi 2 kali sehari, serta kelompok $\mathrm{V}$ diberi benzo[ $\alpha]$ piren, kemudian diberi ekstrak daun dewa dosis $277,8 \mathrm{mg} / \mathrm{BB} / \mathrm{hari}$.

Dosis taurin pada mencit dihitung dengan menggunakan tabel konversi manusia ke mencit ukuran $20 \mathrm{~g}$ menurut Nugraha (2011). Nilai konversi dari manusia ke mencit adalah 0,0026 . Sehingga diperoleh dosis taurin untuk mencit, yaitu $3000 \mathrm{mg} \times 0,0026=7,8 \mathrm{mg} / \mathrm{BB} / \mathrm{hari}$. Dosis yang digunakan untuk sediaan uji adalah 7,8 mg/BB/hari dan 15,6 mg/BB/hari.
Sedian Ekstrak Daun Dewa. Dosis ekstrak daun dewa pada mencit dihitung dengan menggunakan tabel konversi manusia ke mencit adalah 0,0026 , sehingga diperoleh dosis seduhan daun dewa untuk mencit, yaitu 106,84615 x 0,0026 $=0,27779 \mathrm{~g} / \mathrm{BB} / \mathrm{hari}$ sehingga diperoleh $277,8 \mathrm{mg} / \mathrm{BB} / \mathrm{hari}$ (Ngatidjan 1991).

Induksi karsinogenik dilakukan dengan cara menyuntikkan larutan $\mathrm{BaP}$ pada jaringan subkutan mencit di bagian tengkuk. BaP 0,3 mg dilarutkan dalam 0,2 mL minyak jagung. Semua kelompok diinduksi dengan $\mathrm{BaP}$ selama 10 hari kemudian dilanjutkan dengan pemberian zat uji selama 15 hari (Sugitha \& Djalil 1989). Sedangkan untuk kontrol, mencit tidak diinjeksi BaP namun diinjeksi dengan pelarut $\mathrm{BaP}$, yaitu $0,2 \mathrm{~mL}$ minyak jagung.

Pemberian senyawa taurin diberikan pada mencit yang telah diinduksi BaP (kelompok IV).Pemberian zat uji taurin diberikan setiap hari secara oral selama 15 hari setelah munculnya benjolan (nodul) di bagian tengkuk mencit (Juliyarsi \& Melia 2007).

Makanan mencit berupa pakan pelet yaitu comfeedBR II dan minuman mencit berupa air mineral yang diberikan melalui botol gelas minuman. Makanan dan minuman mencit diberikan secara ad libitum (sampai kenyang).

Penghitungan berat badan mencit dengan menggunakan neraca analitik di mulai dari hari pertama, hari ke 10 , hari ke 20 dan hari ke 25 . Hasil selisih berat badan yang dihitung dibuat grafik dengan menggunakan histogram batang.

Mencit yang telah diberi perlakuan dan yang tidak diberi perlakuan dimasukkan ke dalam desikator yang telah diberi klorofom untuk dibius sebelum dibedah. Kemudian darah diambil menggunakan suntikan pada aorta mencit, darah dimasukan ke tabung EDTA. Kemudian dilakukan penghitungan sel darah merah dan sel darah putih, jenis sel darah putih.

Analisis data secara statistik dengan one-way ANOVA menggunakan taraf signifikansi sebesar $5 \%(\alpha=0,05)$ untuk melihat perbedaan pada tiap perlakuan dilanjutkan dengan uji BNT.

\section{HASIL DAN PEMBAHASAN}

Analisis Rerata Berat Badan Mencit (Mus musculus). Pada Gambar 1 terlihat perubahan berat badan mencit hari ke 1 terhadap hari ke 10, 20, dan 25 untuk setiap 
kelompok perlakuan (kelompok kontrol negatif, kelompok kontrol positif, kelompok preventif, kelompok taurin dosis 15,6mg/BB/hari, dan kelompok daun dewa) dipengaruhi oleh diinduksi benzo[ $\alpha]$ piren, taurin, dan ekstrak daun dewa. Walau analisis data terhadap perubahan berat badan mencit secara statistik one-way ANOVA menunjukkan tidak berbeda nyata $(\mathrm{P}>0,05)(\mathrm{Gambar} 1)$. Namun antar perlakuan terlihat adanya kecenderungan penurunan ataupun peningkatan berat badan.

Berat badan merupakan indikator penting untuk menunjukkan adanya infeksi ataupun gangguan fisiologis pada makhluk hidup (Hutomo et al. 2005). Peningkatan berat badan normal terlihat pada kelompok kontrol negatif dan kelompok taurin dengan dosis $15,6 \mathrm{mg} / \mathrm{BB} /$ hari. Sedangkan peningkatan berat badan tertinggi terdapat pada kelompok preventif (kelompok yang diberi taurin $7,8 \mathrm{mg} / \mathrm{BB} / \mathrm{hari}$ sebelum diinduksi BaP. Sebaliknya, penurunan berat badan terjadi pada kelompok kontrol positif dan kelompok pemberian ekstrak daun dewa. Penurunan berat badan terendah, khususnya, terdapat pada kelompok kontrol positif (kelompok yang diinduksi BaP selama 10 hari) pada hari ke 20.

Induksi BaP mengakibatkan penurunan berat tubuh khususnya pada hari ke 20, yang ditunjukan secara berturut-turut oleh kelompok I, IV dan V. Turunnya berat tubuh ini dapat dikatakan sebagai indikator awal dari adanya aktivitas $\mathrm{BaP}$, yaitu dengan melepaskan radikal bebas. Radikal bebas inilah yang selanjutnya berpengaruh terhadap metabolisme tubuh. Radikal bebas yang tinggi akibat induksi $\mathrm{BaP}$ menyebabkan kondisi stres oksidatif, sehingga terjadi peroksidasi lipid pada membran sel dan merusak organisasi membran sel. Menurut Akram (2012), akumulasi $\mathrm{BaP}(P A H)$ dapat membentuk spesies oksigen reaktif (ROS) melalui pembentukan kuinon oleh dihydrodioldehydrogenase. Selanjutnya ROS dapat menyebabkan terjadinya stres oksidatif karena antioksidan tubuh menurun akibat ROS yang terlalu tinggi atau terjadi peningkatan radikal bebas yang dapat menyebabkan kerusakan sel, jaringan atau organ. Hilangnya fungsi seluler diduga mengakibatkan nafsu makan berkurang atau penyimpanan hasil metabolisme makanan berkurang sehingga berat badan mengalami penurunan, yang terlihat jelas pada kelompok kontrol positif.

Analisis Rerata Jumlah Total Sel Darah Merah (Eritrosit). Pada Tabel 1 menunjukkan perbedaan yang signifikan terhadap total sel darah merah $(p<0,05)$ antar kelompok kontrol positif dengan semua kelompok perlakuan lainnya. Menurut Thrall (2004), jumlah sel darah merah mencit normal yaitu dalam kisaran $6,5-10,1 \times 10^{6} \mathrm{sel} / \mathrm{L}$. Dengan demikian, pada kontrol positif terlihat mengalami anemia berat dengan jumlah rerata sel darah merah 3,605 $\pm 0,29710^{6} \mathrm{sel} / \mathrm{L}$ yang hampir menunjukkan 50\% kurang dari jumlah normal.

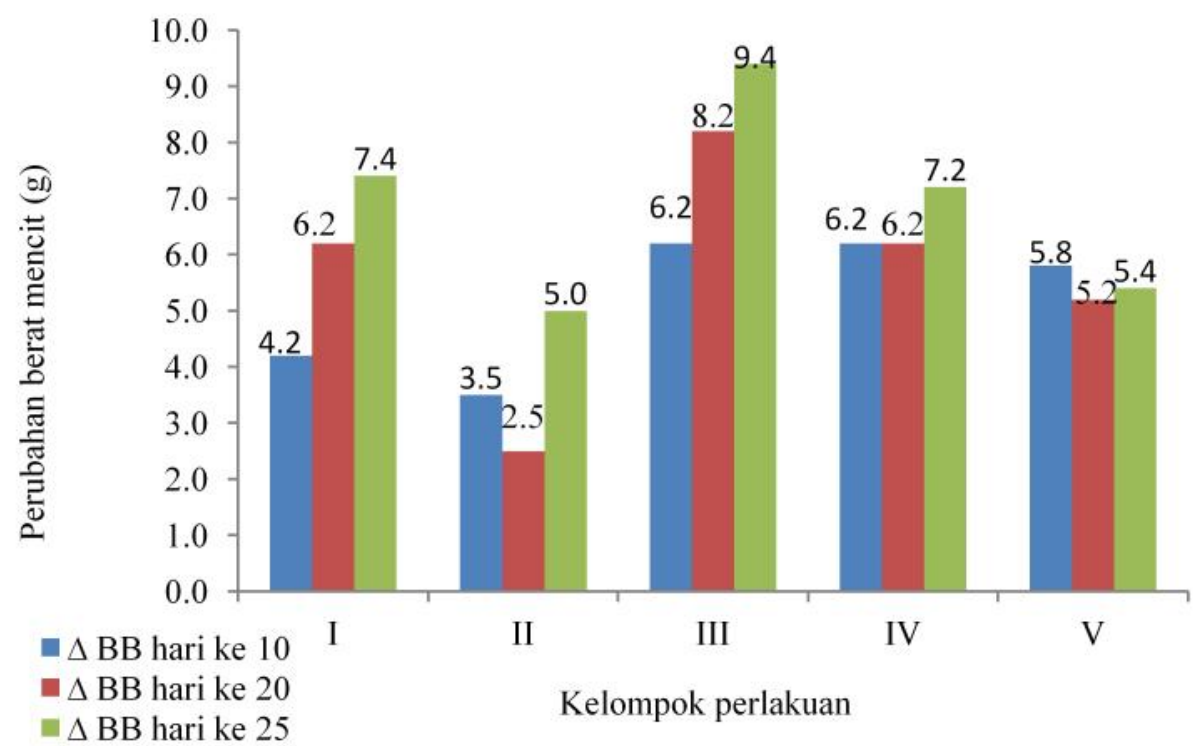

Gambar 1 Selisih penambahan berat badan mencit pada tiap kelompok perlakuanhari ke 1 terhadaphari ke 10, 20, 25 
Diduga zat karsinogen BaP yang terakumulasi pada sel darah merah mencit setelah membentuk radikal bebas merusak membran sel darah merah tersebut melalui kerusakan DNA atau BaP yang terakumulai pada jaringan sumsum tulang merusak hematopoiesis darah dengan merusak DNA, RNA, makronutrien, dan mikronutien pada sel darah merah atau sumsum tulang mencit (Sundaryono 2011). Kerusakan tersebut selanjutnya menyebabkan jumlah sel darah merah sangat kurang dari jumlah normal. Zhu et al. (1995) juga membuktikan induksi (BaP) pada tikus menghasilkan hematotoxicity yang dimanifestasikan sebagai anemia aplastik dan leukemia.

Pada Tabel 1 kelompok kontrol negatif dengan kelompok yang diberi perlakuan (kelompok preventif, kelompok taurin dosis 15,6 mg/BB/hari, dan kelompok yang diberi ekstrak daun dewa) terlihat tidak berbeda nyata $(p>0,05)$, bahkan jumlah sel darah merah pada kelompok perlakuan lebih baik dari kontrol negatif.Hal ini menunjukkan taurin dosis $15,6 \mathrm{mg} / \mathrm{BB} /$ hari yang diberikan pada mencit, setelah diinduksi zat karsinogen $\mathrm{BaP}$, mengalami perbaikan jumlah sel darah merah kembali sehingga menjadi normal bahkan lebih baik dari kontrol negatif. Begitu pula pada kelompok pemberian daun dewa yang mengandung zat flavonoid. Secara in vitro daun dewa telah terbukti mengandung senyawa fenolik yang dapat menghambat radikal bebas (Rivai 2012), yang bersifat antioksidan diduga mampu melakukan proses penghambatan proliferasi sel kanker.

Kelompok preventif juga menunjukkan jumlah sel darah yang normal yaitu $8,891 \pm 0,872 \times 10^{6} \mathrm{sel} / \mu \mathrm{L}$ (Tabel 2). Mencit kelompok ini diberi taurin 7,8 mg/BB/hari selama 15 hari sebelum diberi karsinogen selama 10 hari.

Tabel 2 Rerata jumlah total jenis leukosit
Dari jumlah sel darah tersebut menunjukkan tidak terjadi anemia dan jumlah sel darah merah tetap normal. Hal ini karena kandungan taurin yang diberikan pada mencit sebelumnya cukup mampu meningkatkan antioksidan terhadap zat karsinogen BaP.

Analisis Rerata Jumlah Total Sel Darah Putih (Leukosit). Pada Tabel 3 menunjukkan bahwa kontrol positif memiliki jumlah leukosit yang berbeda nyata $(p<0,05)$ terhadap semua kelompok perlakuan lainnya. Sedangkan antara kelompok kontrol negatif dengan kelompok preventif, kelompok taurin dosis 15,6 mg/BB/

Tabel 1 Rerata jumlah sel darah merah (eritrosit) pada setiap kelompok perlakuan

\begin{tabular}{cc}
\hline Kelompok perlakuan & Rerata jumlah eritrosit \\
$10^{6} \mathrm{sel} / \mathrm{L}$ \\
\hline I & $7,864 \pm 1,394^{\mathrm{a}}$ \\
II & $3,605 \pm 0,297^{\mathrm{b}}$ \\
III & $8,891 \pm 0,872^{\mathrm{a}}$ \\
IV & $8,132 \pm 2,465^{\mathrm{a}}$ \\
V & $8,180 \pm 0,602^{\mathrm{a}}$ \\
\hline
\end{tabular}

Angka yang diikuti huruf a tidak berbeda nyata Angka yang diikuti huruf $\mathrm{b}$ berbeda nyata pada taraf $5 \%$

Tabel 3 Rerata jumlah sel darah putih (leukosit) pada kelompok perlakuan

\begin{tabular}{cc}
\hline Kelompok perlakuan & $\begin{array}{c}\text { Rerata jumlah leukosit } \\
10^{3} \text { cell/ L }\end{array}$ \\
\hline I & $6,610 \pm 0,699^{\mathrm{b}}$ \\
II & $14,170 \pm 3,898^{\mathrm{a}}$ \\
III & $7,070 \pm 0,849^{\mathrm{b}}$ \\
IV & $6,770 \pm 1,066^{\mathrm{b}}$ \\
V & $6,440 \pm 0,513^{\mathrm{b}}$ \\
\hline
\end{tabular}

Angka yang diikuti huruf $\mathrm{b}$ tidak berbeda nyata

Angka yang diikuti huruf a berbeda nyata pada taraf 5\%

\begin{tabular}{cccccc}
\hline \multirow{2}{*}{ Kelompok perlakuan } & \multicolumn{5}{c}{ Rerata jumlah jenis leukosit (\%) } \\
& Limfosit & Monosit & Neutrofil & Eosinofil & Basofil $^{*}$ \\
I & $72,60 \pm 9,91^{\mathrm{a}}$ & $2,80 \pm 1,64^{\mathrm{a}}$ & $23,80 \pm 10,06^{\mathrm{b}}$ & $0,80 \pm 1,09^{\mathrm{a}}$ & $0,00 \pm 0,00$ \\
II & $65,25 \pm 13,77^{\mathrm{a}}$ & $2,75 \pm 0,96^{\mathrm{a}}$ & $30,50 \pm 13,33^{\mathrm{b}}$ & $1,50 \pm 1,73^{\mathrm{a}}$ & $0,00 \pm 0,00$ \\
III & $75,00 \pm 14,30^{\mathrm{a}}$ & $2,80 \pm 1,79^{\mathrm{a}}$ & $18,60 \pm 9,99^{\mathrm{b}}$ & $3,60 \pm 3,29^{\mathrm{a}}$ & $0,00 \pm 0,00$ \\
IV & $42,60 \pm 14,05^{\mathrm{b}}$ & $2,80 \pm 1,79^{\mathrm{a}}$ & $51,60 \pm 13,20^{\mathrm{a}}$ & $3,00 \pm 1,22^{\mathrm{a}}$ & $0,00 \pm 0,00$ \\
V & $66,60 \pm 13,61^{\mathrm{a}}$ & $2,80 \pm 1,80^{\mathrm{a}}$ & $27,00 \pm 11,25^{\mathrm{b}}$ & $3,60 \pm 3,29^{\mathrm{a}}$ & $0,00 \pm 0,00$ \\
$\begin{array}{c}\text { Persentase Normal } \\
\text { (AML 2013) }\end{array}$ & $60 \%-95 \%$ & $0,1 \%-4 \%$ & $7 \%-31 \%$ & $0 \%-6 \%$ & $0 \%-1 \%$ \\
\hline
\end{tabular}

*) Tidak pengaruh pada tiap perlakuan 
hari, dan kelompok yang diberi daun dewa tidak menunjukkan perbedaan yang signifikan.

Diketahui bahwa dalam keadaan normal, darah perifer mencit mengandung leukosit dengan jumlah berkisar 2,61-10,05 x 10 3 sel/ L (Thrall 2004). Kisaran jumlah leukosit tersebut dimiliki oleh empat kelompok perlakuan, kecuali kelompok kontrol positif (pemberian BaP saja) dengan rerata jumlah total leukosit $14,170 \pm 3,898 \times 10^{3} \mathrm{sel} / \mathrm{L}$. Apabila di dalam darah jumlah leukosit lebih dari $11.000 \mathrm{sel} / \mathrm{mm}^{3}$ disebut leukositosis (menderita penyakit leukemia) dan bila kurang dari $4.000 \mathrm{sel} / \mathrm{mm}^{3}$ disebut leukopenia (Playfair \& Chain 2001).

Berdasarkan analisis rerata jumlah total sel darah putih kelompok kontrol positif yang diinduksi BaP sampai hari ke 10 mengalami kenaikan jumlah sel darah putih yang sangat tinggi mencapai $40 \%$ dari jumlah normal yaitu $14,170 \pm 3,898 \times 10^{3} \mathrm{sel} / \mathrm{L}$. Hal ini terjadi diduga karena pada kontrol positif yang telah diinduksi zat karsinogen BaP, mengalami akumulasi pada sel darah dalam proses metabolisme di dalam tubuh mencit.

Pada kelompok preventif dan kelompok taurin dosis $15 \mathrm{mg} / \mathrm{BB} /$ hari terlihat jelas jumlah leukosit tidak berbeda nyata dengan kelompok kontrol negatif $(p>0,05)$, dengan jumlah rerata sel darah putih 7,070 $\pm 0,849 \times 10^{3} \mathrm{sel} / \mathrm{L}$ dan $6,770 \pm 1,066 \mathrm{x} 10^{3} \mathrm{sel} / \mathrm{L}$. Hal ini diduga pada kelompok mencit yang diberi taurin dengan dosis 15,6 mg/BB/hari yang selanjutnya diinduksikan BaP, mampu melakukan perbaikan jaringan dari oksidan $\mathrm{BaP}$ pada sel-sel darah mencit sehingga sel-sel darah menjadi stabil dan normal kembali.

Analisis Hitung Jenis Leukosit Pada Kelompok Perlakuan. Pada Tabel 2 menunjukkan bahwa jumlah persentase limfosit pada kontrol normal dengan kontrol positif, kelompok taurin dosis 15,6 mg/BB/hari, dan kelompok preventif tidak berbeda nyata $(\mathrm{P}>0,05)$, dengan kisaran normal limfosit pada mencit adalah 60-95\% (AML 2013). Hal ini menunjukkan bahwa limfosit pada kontrol positif hanya berperan pada respon imun yang spesifik. Limfosit B berfungsi untuk menghasilkan antibodi (respon imun humoral), sedangkan limfosit $\mathrm{T}$ berperan dalam respon imun selular (Munasir 2001).

Pada kelompok taurin dosis $15,6 \mathrm{mg} / \mathrm{BB} / \mathrm{hari}$ terlihat jumlah limfosit berada dibawah normal, hal ini diduga taurin yang diberikan setelah zat $\mathrm{BaP}$ diinduksikan mempunyai sifat sebagai antioksidan dan mampu meningkatkan fungsi dari sel darah putih. Menurut Stapleton et al. (1998), taurin berperan penting dalam berbagai fungsi fisiologis, seperti osmoregulasi, antioksidasi, detoksifikasi, dan stimulasi glikolisis serta glikogenesis, bahkan pada beberapa sel tubuh, asam amino taurin tetap pada konsentrasi yang tinggi. Penelitian lain menunjukkan bahwa taurin mampu memberikan perlindungan pada limfosit (Islambulchilar et al. 2011).

Pada kelompok preventif terlihat jelas jumlah limfosit tertinggi dengan jumlah persentase limfosit 75,00 \pm $14,30 \%$. Hal ini diduga taurin bersifat melindungi lymfoblast sel darah putih sehingga mampu meningkatkan daya hidup limfosit. Seperti yang dinyatakan Stapleton et al. (1998), bahwa taurin mempunyai efek perlindungan terhadap sel lymfoblast yang berkaitan dengan sifat taurin sebagai antioksidan. Dengan demikian dapat dikatakan bahwa BaP yang terakumulasi dalam darah membentuk ROS mampu distabilkan oleh taurin. Penelitian Islambulchilar et al. (2011), menyatakan bahwa taurin mampu meningkatkan jumlah dan viabilitas limfosit. Sehingga diduga konsentrasi taurin yang tinggi pada limfosit diperkirakan juga memiliki peran dalam sistem imun. Levy (1998) juga menyatakan bahwa taurin dapat mencegah kerusakan limfosit akibat radikal bebas dan memfasilitasi proteksi seluler melalui stabilisasi membran.

Pada kelompok mencit yang diberi ekstrak daun dewa, terlihat jumlah limfosit juga dalam persentase kisaran normal, walau kelompok ini telah diinduksi dengan zat karsinogen BaP. Seperti sebelumnya telah dinyatakan, flavonoid yang terdapat pada ekstrak daun dewa, bersifat antioksidan terhadap BaP. Selanjutnya Joao et al. (2014), juga menyatakan bahwa flavonoid mempengaruhi inflamasi, produksi sitokin, produksi limfosit, dan granulosid melalui mekanisme proteksi terhadap radikal bebas, regulasi NO, dan metabolisme asam arahidonat (asam lemak omega-3 bersifat anti-inflamasi). Disamping itu, diduga juga flavonoid dapat menangkap radikal bebas dengan melepaskan atom hidrogen dari gugus hidroksilnya. Pemberian atom hidrogen ini menyebabkan radikal bebas menjadi stabil dan berhenti melakukan gerakan ekstrem, sehingga tidak merusak lipid, protein, dan DNA (materi genetik) yang menjadi target kerusakan seluler (Sundaryono 2011). 
Pada Tabel 2 rerata persentase monosit, menunjukkan bahwa setiap kelompok perlakuan tidak memperlihatkan perbedaan yang signifikan $(p>0,05)$, semuanya dalam kisaran yang normal. Jumlah normal monosit pada mencit adalah 0-4\% (AML 2013). Pada setiap perlakuan, diduga diinduksi BaP tidak mempunyai pengaruh untuk menginduksi sekresi monosit, sehingga monosit mempunyai jumlah yang normal untuk setiap perlakuan seperti pada kontrol negatif yaitu $2,8 \pm 1,6 \%$.

Monosit dibentuk di dalam sumsum tulang, masuk ke dalam sirkulasi dalam imatur dan mengalami proses pematangan menjadi makrofag setelah masuk ke jaringan (Suhermanto 2011). Sesuai dengan fungsi monosit sebagai makrofag yang mampu memfagositosis bakteri dan mikroorganisme lainnya, setiap kelompok menunjukkan tidak terdapat mikroorganisme yang masuk ke dalam tubuh, karena monosit berperan penting dalam reaksi imunologi dengan cara membentuk protein dari suatu komplemen dan mengeluarkan substansi yang mempengaruhi terjadinya proses peradangan kronik (Munasir 2001)

Pada analisis rerata jumlah neutrofil (Tabel 2) kelompok taurin dosis $15,6 \mathrm{mg} / \mathrm{BB} / \mathrm{hari}$ berbeda sangat signifikan $(p<0,05)$ terhadap kelompok kontrol negatif, kelompok kontrol positif, kelompok preventif, dan kelompok dosis daun dewa. Diketahui bahwa jumlah neutrofil terbanyak kedua setelah sel limfosit dalam peredaran darah perifer sebesar 7-31\% dari total leukosit (AML 2013). Neutrofil merupakan garis pertama dari pertahanan melawan dan menyerbu mikroorganisme, trauma jaringan, dan banyak faktor yang menyebabkan peradangan (Teske 2010).

Pada kelompok mencit yang diberi taurin dosis $15,6 \mathrm{mg} / \mathrm{BB} / \mathrm{hari}$ terlihat jumlah neutrofil mencapai $30 \%$ lebih dari jumlah neutrofil normal (Tabel 2). Hal ini menunjukkan taurin mampu meningkatkan jumlah leukosit normal untuk melawan infeksi akibat induksi zat oksidan BaP melalui suntikan. Menurut Stapleton et al. (1998), taurin mampu meningkatkan jumlah dan fungsi neutrofil dan bahkan menunda apoptosis neutrofil akibat infeksi. Netrofilia merupakan peningkatan jumlah neutrofil dari kisaran normal. Dengan demikian karena jumlah dalam persen kelompok mencit yang mendapat taurin dosis $15,6 \mathrm{mg} / \mathrm{BB} / \mathrm{hari}$ dapat dikatakan mengalami netrofilia.
Netrofilia dapat diakibatkan oleh peradangan, stres, respon kortikosteroid, latihan yang berlebih, dan respon epinefrin (Ramon 2007).

Persentase neutrofil tidak mengalami perbedaan yang signifikan pada kelompok kontrol positif. Hal ini menunjukkan pada kontrol positif tidak bisa meningkatkan fungsi dan jumlah jenis leukosit, kondisi ini diduga dikarenakan zat oksidan BaP telah terakumulasi pada selsel di jaringan dan organ mencit sehingga zat oksidan $\mathrm{BaP}$ mempercepat proses apoptosis sel diferensiasi leukosit tersebut dan menyebabkan sel-sel normal menjadi sel mutagenik. Menurut Sumpena et al. (2009), sebagai senyawa karsinogen, $\mathrm{BaP}$ dapat menimbulkan mutasi gen yang dapat dimanifestasikan sebagai kerusakan kromosom, yaitu terjadi aberasi atau terbentuk patahan kromosom.

Selanjutnya untuk jumlah eosinofil pada setiap kelompok perlakuan juga tidak menunjukkan perbedaan yang signifikan $(p>0,05)$ (Tabel 3). Eosinofil sendiri adalah bagian dari sel darah yang berperan dalam merespon parasit ataupun benda asing dalam tubuh (Lesty et al. 2012). Dengan demikian, kondisi jumlah eosinofil yang tidak berbeda nyata antar perlakuan menunjukkan setiap perlakuan tidak terjadi alergi atau infeksi parasit dan benda asing yang berarti, terutama pada kelompok kontrol negatif dengan jumlah yang paling rendah yaitu $0,8 \pm 1,095 \%$. Jumlah eosinofil normal sekitar 0-6\% (AML 2103), dari total leukosit dan akan meningkat bila terjadi reaksi alergi, infeksi parasit dan benda asing (Lesty et al. 2012). Jumlah eosinofil cenderung rendah pada saat stres, pelepasan kortikosteroid, dan infeksi akut (Kusnugroho 2014). Sebab stres juga memicu hypothalamus mensekresikan hormon kortisol yang menekan sistem imun sehingga berdampak menurunkan jumlah eosinofil.

Hasil pengamatan pada jumlah basofil menunjukkan setiap perlakuan tidak berpengaruh sama sekali pada jumlah persentase basofil (Tabel 2). Jumlah basofil normal adalah 0-1\% (AML 2013). Tidak terdeteksinya basofil, diduga akibat stres yang mungkin terjadi selama perlakuan.

\section{SIMPULAN}

Berdasarkan hasil penelitian yang telah dilakukan, bahwa taurin mempunyai efek preventif dan terapoitik terhadap kerusakan sel-sel darah yang diinduksi BaP 
0,3 mg mg/BB/hari. Kemampuan terapoetik taurin lebih baik dari ekstrak daun dewa.

\section{UCAPAN TERIMAKASIH}

Ucapan terima kasih ditujukan kepada Kepala Bagian dan Staf Laboratorium Biologi Molekuler FMIPA Universitas Lampung, untuk penyediaan tempat diadakannya penelitian khususnya kepada Ibu Endang Linirin Widiastuti, Ph.D. Ucapan terima kasih juga ditujukankepada Kepala Bagian dan Staf Patologi Anatomi BPPV Regional III Bandar Lampung terutama untuk konsultasi yang diberikan selama pengerjaan karya tulis dan seluruh pihak yang telah membantu penulis dalam menyelesaikan artikel ini.

\section{DAFTAR PUSTAKA}

Akram. 2012. Mekanisme kemopreventif ekstrak heksan biji jinten hitam ( Nigela sativa Lor) pada tikus sprague dawley diinduksi 7,12 DimethylBenz(a)antracene : kajian antioksidan dan immunomodulator Disertasi. Yogyakarta: UGM.

AML (American Medical Laboratory). 2013. Mouse hematology. http://en.aml-vet.com/animal-species/ mouse/hematology (4 Maret 2013).

Anand, P., Rajakumar, D., Jeraud, M., Felix, A.J \& Balasubramanian, T. 2011. Effectsof taurine on glutathione peroxidase, glutathione reductase and reduced glutathione levels in rats. Pak J.Biol.Sci 14: 219-225.

Gangar, S.C., Sandhir, R \& Koul, A. 2010. Effects of Azadiracha indica on certain hematological parameters during benzo(a)pyrene induced murine forestomach tumorigenesis. European Journal of Medical and Pharmacological Sciences. Punjab University. Chandigarh (India).

Hanahan, D \& Weinberg, R.A. 2000. The hallmark of cancer. Cell. 100: 57-70.

Hanahan, D \& Weinberg, R.A. 2011.Hallmarks of cancer: the next generation[J]. Cell 144(5): 646-674.

Hutomo, Rahadi, Sutarno, Winarno \& Kusmardi. 2005. Uji Antimalaria EkstrakBuah Morinda citrifolia dan AktivitasMakrofag pada Mencit (Musmusculus) setelah Diinfeksi Plasmodium berghei. Biofarmas 3(2): 61-69.

Hynek, D.L. Krejcova, J., Sochor, N., Cernei, J. Kynicky, V., Adam, L., Trnkova, J., Hubalek, R., Vrba, R \& Kizek. 2012. Study of interactions betweencysteine and cadmium(ii) ions using automatic pipetting system off-line coupled with electrochemical analyser dedicated united nationenvironment program: lead and cadmium initiatives. Int J Electrochem Sci 7(3): 1802-1819.

IARC. 2010. IARC Monographs on the Evaluation of Carcinogenic Risks to Humans. Some Nonheterocyclic Polycyclic Aromatic Hydrocarbons and Some Related Exposures. France: Lyon.

Islambulchilar, M.I., Asvadiz, Z., Sanaat, A., Esfahaniz, M.R \& Sattari. 2011. Effect of taurine on febrile episodes in acute lymphoblastic leukemia. Adv Pharm Bull 2015 5(1): 103-108.

João Henrique, G., Lago., Alessandra, C., Toledo-Arruda., Márcia Mernak., Kaidu, H., Barrosa., Milton, A., Martins., Iolanda, F.L.C., Tibério \& Carla, M., Prado. 2014. Structure-Activity Association of Flavonoids in Lung Diseases. Molecules 2014,19, 35703595; doi:10.3390/molecules 9033570.ISSN 14203049.

Juliyarsi, I \& Melia, S. 2007. Dadih Susu Sapi Mutan Lactococcus lactis Sebagai Food Healhty Dalam Menghambat Kanker. Artikel Penelitian. Padang: Universitas Andalas.

Kusnugroho, D.B.P \& Siahaan, D. 2014. Eosinopenia sebagai Penanda Diagnosis Sepsis. CDK 41(10): 741744.

Levy, J. 1998. Immunonutrition: the pediatric experience. Nutrition 14(7): 641-7.

Lesty, H., Sumah, M., Nindatu, M \&Kakisina, P. 2012. Efek pemberian ekstrak metanol kulit batang pohon pulai (Alstonia scholaris L. R. Br.) terhadap hasil diferensiasi leukosit mencit (mus musculus) yang diinfeksi plasmodium berghei anka. Molucca Medica 5(1): 39-53.

Munasir, Z. 2001. Respons imun terhadap infeksi bakteri. sari pediatri. 2(4): 193-197.

Ngatidjan. 1991. Petunjuk Laboratorium: Metode laboratorium dalamtoksikologi. Pusat Antar Universitas Bioteknologi Universitas Gajah Mada. Yogyakarta.

Nugraha, L.S.A. 2011. Cara dan Rute Pemberian Obat Pada Hewan Percobaan Mencit. Akademi Farmasi Theresiana. Semarang.

Playfair, J.H.L \& Chain, B.M. 2001. Immunology at a Glance Seventh edition. Blackwell Publishing Company. London: 8-63.

Pushpakiran, G., Mahalakshmi, K \&Anuradha, C.V. 2004. Protective effects of taurine on glutathione and glutathione-dependent enzymes in ethanol-fed rats. Pharmazie 59(11): 869-872.

Putri, C.A.R. 2007. Efek Infutum Daun Dewa (Gynura segetum [Lour.] Merr) Terhadap Hambatan Respon Rasa Nyeri.Tesis. Surabaya: Universitas Airlangga.

Ramon, A. 2007. Analisis Paparan BenzenaTerhadap Profil Darah Pada Pekerja Industri Pengolahan Minyak Bumi. Tesis. Semarang Universitas Diponegoro. 
Rivai, H. 2012. Identifikasi Senyawa Antioksidan Dari Daun Dewa (Gynura pseudochina (Lour.) DC). Jurnal Sains dan Teknologi Farmasi 17(1): 84-91.

Sajuthi, D. 2001. Ekstraksi, Fraksinasi, Karakterisasi, dan Uji Hayati In VitroSenyawa Bioaktif Daun Dewa (Gynura pseudochina [Lour.] DC) Sebagai Antikanker, tahap II. Bogor: Jurusan Kimia IPB.

Shao, A \& Hathcock, J.N. 2008. Risk assessment for the amino acids taurine, l-glutamine and l-arginine. Regul Toxicol Pharmacol 50(3): 376-399.

Sinha, M., Manna, P \& Sil, P.C. 2007. Amelioration of galactosamine-induced nephrotoxicity by a protein isolated from the leaves of the herb. Cajanus indicus L. Complemen Altern Med 7(11): 1-18.

Stapleton, Philip P; O'F laherty, L ean; R edmond, Paul dan Boucher Hayes \& David J. 1998. Neuroprotective Mechanisms of Taurine against IschemicStroke. brain sciences www.mdpi.com/journal/brainsci.

Sumpena, Y., Sofyan, R \& Rusilawati, R. 2009. Uji mutagenisitas benzo $[\alpha]$ piren dengan metode mikronukleus pada sumsum tulang mencit albino (Mus musculus). Cermin Dunia Kedokteran 36(1): 33-36.

Sundaryono. 2011. Uji aktivitas senyawa flavonoid total dari gynura segetum (Lour) terhadap peningkatan eritrosit dan penurunan leukosit pada mencit (Mus musculus). Jurnal Exacta 9(2): 8-16.

Suhermanto, A., Andayani, S \& Maftuch. 2011. Pemberian total fenol teripang pasir (Holothuria scabra) untuk meningkatkan leukosit dan diferensiasi leukosit ikan mas (Cyprinus carpio) yang diinduksi bakteri Aeromonas Hydrophila. Jurnal KELAUTAN 4(2): 4959.

Sugitha, I.M \& Djalil., M. 1989. Susu, Penanganan dan Teknologinya. Fakultas Peternakan. Padang: Universitas Andalas.

Syafei \& syafrizal. 2009. Eritropoetin rekombinan pada penderita kanker. Cermin Dunia Kedokteran 36(1): 13-15.

Thrall, M.A. 2004. Veterinary Hematology and Clinical Chemistry. Maryland: Lippincott Williams dan Wilkins.

Teske, E. 2010. Leucocytes. Di dalam: Douglas J Weiss, K Jane Wardrop, editor. Schalm's Veterinary Hematology Sixth Edition. United States of America: WileyBlackwell.

Zhang, X., Bi, C., Fan, Y., Cui, C., Chen, D., Xiao, Y \& Dou, QP. 2008. Induction of tumor cell apoptosis by taurine Schiff basecopper complex is associated the with inhibition of proteasomal activity. Int $\mathrm{J} \mathrm{Mol} \mathrm{Med}$ 22(5): 677-682.

Zhu, H., Li, Y \& Trush, M.A. 1995.Characterization of benzo $[\alpha]$ pyrene quinone-induced toxicity to primarycultured bone marrow stromal cells from DBA/ 2 mice: potential role of mitochondrial dysfunction. Toxicol Appl Pharmacol 130(1): 108-120. 